\title{
MODEL PEMBELAJARAN SMASH BOLAVOLI PADA SISWA SEKOLAH MENENGAH KEJURUAN
}

\author{
RAJU RAHADIAN \\ Universitas Negeri Jakarta \\ rahadianraju@gmail.com
}

\begin{abstract}
ABSTRAK
Secara umum tujuan dari penelitian ini adalah menghasilkan produk berupa model pembelajaran smash bolavoli untuk siswa SMK. Memperoleh data data empiris tentang efektivitas model pembelajaran smash bolavoli untuk siswa SMK. Pendekatan penelitian pengembangan model pembelajaran smash ini menggunakan model penelitian dan pengembangan (Research and Development) dari Borg dan Gall. Hasil analisis kebutuan menunjukan bahwa model pembelajaran smash bola voli sangat dibutuhkan oleh para guru pendidikan jasmani untuk menunjang proses Kegiatan Belajar Mengajar (KBM). Hasil pengembangan model pembelajaran smash bolavoli berdasarkan validasi 5 ahli diperoleh 26 model dari 34 model yang peneliti susun. Hasil uji coba kelompok kecil kemudahan dan kemenarikan model pembelajaran smash bolavoli diperoleh nilai 76,30\% (baik) dan $80.56 \%$ (sangat baik). Hasil uji coba kelompok besar, kemudahan dan kemenarikan model pembelajaran smash bolavoli diperoleh nilai $71,75 \%$ (baik) dan $75.36 \%$ (baik). Keefektifan model yang dikembangkan dinyatakan efektif untuk digunakan. Berdasarkan dari hasil perbandingan antara nilai pretest dan posttest yang diberikan kepada siswa diperoleh hasil $t_{0}$ sebesar 11,895 dan $t_{\text {tabel }} 2,042$. Sehingga dapat disimpulkan terdapat perbedaan antara hasil smash bolavoli peserta didik setelah diberikan perlakuan model pembelajaran smash bolavoli.
\end{abstract}

Kata Kunci: Model Pembelajaran, Smash, Bolavoli, Siswa SMK

\section{PENDAHULUAN}

Pendidikan Sekolah Menengah Kejuruan (SMK) adalah menyiapkan siswa menjadi tenaga kerja yang terampil produktif dan mampu menciptakan lapangan kerja. Oleh karena itu lulusan siswa SMK harus memiliki karakter yang kuat sebelum terjun ke dunia kerja. Lembaga pendidikan memiliki peranan penting terhadap pembentukan karakter siswa. Pembentukan karakter itu sendiri tidak lepas dari adanya pelajaranpelajaran yang mengarah pada pendidikan pembentukan karakter siswa, salah satunya pendidikan jasmani. Pendidikan jasmani sangat bagus didalam membentuk karakter dan mental siswa menjadi lebih baik. 
Program pendidikan jasmani memiliki kepentingan yang relatif sama dengan program pendidikan yang lainnya dalam ranah pembelajaran, yaitu sama-sama mengembangkan tiga ranah utama, psikomotor, kognitif dan afektif. Pembelajaran pendidikan jasmani menuntut beberapa standar kompetensi yang harus dikuasai oleh siswa. Materi ajar smash bolavoli merupakan salah satu standar kompetensi yang telah ditetapkan dalam pendidikan jasmani yang diajarkan di SMK. Namun dalam kondisi dilapangan materi pembelajaran smash belum berjalan optimal dan maksimal.

Berdasarkan fakta dilapangan, masih terdapat beberapa guru yang cenderung hanya memberikan beberapa materi ajar teknik dasar bolavoli tertentu saja kepada siswa, misalnya teknik dasar passing dan teknik dasar serve. Kondisi ini mengakibatkan penguasaan keterampilan dasar smash siswa pada permainan bolavoli masih rendah. Ditambah kurangnya motivasi siswa dalam pembelajaran praktek permainan bolavoli terutama materi smash yang disebabkan oleh beberapa faktor, seperti siswa kurang konsentrasi memperhatikan dan melaksanakan praktek pembelajaran smash bolavoli, siswa kurang antusias dan tidak aktif saat praktek pembelajaran smash, siswa menganggap materi smash merupakan materi yang sulit, materi ini hanya untuk atlet yang profesional. Guru kurang inovatif pada saat praktek pembelajaran smash bolavoli. Guru masih kekurangan model-model pembelajaran smash dengan model yang tepat dan mudah untuk meningkatkan keterampilan dasar smash bolavoli.

Berdasarkan penjelasan dan fakta yang terjadi di lapangan, maka peneliti sangat tertarik untuk mengadakan penelitian tentang "Pengembangan Model Pembelajaran Smash Bolavoli Pada Siswa Sekolah Menengah Kejuruan”.

Menurut James Tangkudung (2016: 7) Penelitian pengembangan (development research) merupakan penelitian yang dipergunakan untuk menciptakan produk baru dan dapat mengembangkan produk yang telah ada berdasarkan analisis kebutuhan yang terdapat dilapangan (observasi, wawancara, kuisioner kebutuhan awal). Model penelitian pengembangan (Research and Development) disebut juga sebagai researchbased develompment merupakan model penelitian yang mengembangkan produk baru dan menyempurnakan produk yang telah ada. Hal ini didukung oleh Sugiyono (2012: 407) yang mendefinisikan model penelitian dan pengembangan sebagai "model penelitian yang digunakan untuk menghasilkan produk tertentu dan menguji keefektifan produk tersebut". Menurut Bayu Kharisma (2014: 9), Penelitian pengembangan tidak selalu mengembangkan produk baru, bisa dengan menyempurnakan produk yang telah ada dandapat dipertanggungjawabkan. Penelitian dan pengembangan selalu diawali dengan adanya kebutuhan, permasalahan yang membutuhkan pemecahan dengan menggunakan suatu produk tertentu. 
Dalam penelitian ini model pembelajaran yang akan dikembangkan adalah model pembelajaran pendidikan jasmani untuk meningkatkan hasil belajar smash untuk siswa Sekolah Menengah Kejuruan.

Menurut Samsudin (2008: 18) Pendidikan jasmani adalah suatu proses pembelajaran melalui aktivitas jasmani yang didesain untuk meningkatkan kebugaran jasmani, mengembangkan keterampilan motorik, pengetahuan dan perilaku sehat dan aktif, sikap sportif, dan kecerdasan emosi." Menurut Anas Junaedi dan Heri Wisnu, (2015: 813) Pendidikan jasmani, olahraga, dan kesehatan merupakan bagian dari pendidikan nasional yang harus melibatkan unsur-unsur penting berupa fikiran dan tubuh. Dimana semua aspek tersebut sangat berkaitan dalam kehidupan sehari-hari untuk menjadikan masing-masing individu agar menjadi baik.

Menurut Novi Dian Anggraini dkk. (2014: 82) tujuan pendidikan jasmani, olahraga, dan kesehatan adalah untuk mengembangkan individu (seseorang) dalam kebugaran jasmani, petumbuhan fisik, mental serta moral yang berupa sikap sportif, jujur, disiplin, bertanggung jawab, kerjasama, percaya diri, dan demokratis melalui aktivitas jasmani.

Pendidikan jasmani juga sebagai alat dalam membentuk karakter. Menurut Soedjatmiko, Atip Nurcahyani (2015: 9) Karakter dalam pendidikan jasmani adalah konsep dari moral, yang tersusun dari sejumlah karakteristik yang dapat dibentuk melalu aktivitas olahraga. Setidaknya terdapat nilai-nilai yang baik yang dapat dibentuk melalui aktivitas olahraga, antara lain: rasa terharu (compassion), keadilan (fairness), sikap sportif (sport-personship), dan integritas (integrity).

Berdasarkan uraian di atas pendidikan jasmani dalam pengembangan model pembelajaran smash ini bertujuan untuk mengembangkan individu (seseorang) dalam kebugaran jasmani, petumbuhan fisik, mental serta moral yang berupa sikap sportif, jujur, disiplin, bertanggung jawab, kerjasama, percaya diri, dan demokratis sehingga pada akhirnya dapat membentuk karakter seseorang.

Direktorat (1986: 21) Smash Bolavoli adalah pukulan yang keras yang diarahkan kepetak lawan dan berfungsi sebagai serangan. Biasanya itu merupakan akhir, karena menurut peraturan bola voli hanya boleh 3 kali pukulan dalam satu petak sehingga tiap kali pukulan ke 3 yang harus diarahkan ke petak lawan. Smash merupakan suatu pukulan dimana tangan kontak dengan bola secara penuh pada bagian atas, sehingga jalannya bola terjal dengan kecepatan yang tinggi. Dalam permainan Bolavoli, smash merupakan salah satu teknik yang harus dikuasai oleh seorang pemain bolavoli.

Menurut Kinda (2006: 56) Smash adalah senjata ampuh untuk menyerang, baik itu berupa sulitnya lawan untuk melakukan serangan maupun langsung mendapatkan 
angka. Pemain yang melakukan smash mendapatkan kesempatan pertama memperoleh angka untuk timnya, apabila smash tidak dapat diterima oleh lawan atau langsung jatuh di petak lawan. Kecuali smash itu menyangkut di net, keluar dari lapangan, atau kesalahan dalam melakukan smash, hal tersebut mengakibatkan lawan justru mendapat nilai atau angka. Adapun tahapan dalam melakukan gerakan smash terdiri dari empat tahap, tahapan pertama yaitu tahapan awalan atau run up (lari menghampiri), tahap kedua yaitu take off (lepas landas), tahap ketiga hit (memukul bola pada saat melayang di udara), dan tahap keempat yaitu landing (mendarat).

Berdasarkan uraian yang telah dijelaskan, yang dimaksud dengan smash bolavoli dalam penelitian ini adalah teknik gerakan smash yang benar dalam permainan bolavoli yang meliputi: Run up (awalan), take off (lepas landas), hit (memukul bola di udara) dan landing (mendarat) sehingga menghasilkan serangan di dalam permainan bolavoli dengan cara memukul bolavoli sekeras mungkin sehingga jalannya bola terjal dengan kecepatan tinggi dan dapat menghasilkan poin.

Kegiatan belajar mengajar yang terjadi saat ini tentu saja merupakan satu rangkaian kegiatan yang terjadi oleh interaksi antara guru dan peserta didik tentunya untuk mencapai tujuan pendidikan. Menurut Husdarta (2010:3) Sebutan "peserta didik" itu menggantikan sebutan "siswa" atau "murid" atau "pelajar" atau "student". Penyebutan peserta didik tentunya akan memberikan perlakuan secara menyeluruh dalam proses belajar mengajar dimana ada interaksi antar kedua pelaku pembelajaran.

Pendidikan menengah kejuruan adalah pendidikan pada jenjang pendidikan menengah yang mengutamakan pengembangan kemampuan siswa untuk melaksanakan jenis pekerjaan tertentu. Hal ini sesuai dengan pendapat Ace Suryadi (2002: 156) menjelaskan bahwa pendidikan menengah kejuruan mengutamakan pengembangan kemampuan siswa untuk melaksanakan suatu jenis pekerjaan, menyiapkan siswa memasuki lapangan kerja, serta mengembangkan sikap profesional. Definisi pendidikan kejuruan menurut para ahli (Wardiman 1998: 33-34) dijelaskan sebagai berikut:

1) Rupert Evans pendidikan kejuruan adalah bagian dari sistem pendidikan yang mempersiapkan seseorang agar lebih mampu bekerja pada satu kelompok pekerjaan atau satu bidang pekerjaan dari pada bidang-bidang pekerjaan lainnya.

2) United States Congress pendidikan kejuruan adalah program pendidikan yang secara langsung dikaitkan dengan penyiapan seseorang untuk suatu pekerjaan tertentu atau untuk persiapan tambahan karier seseorang. 
3) Menurut Undang-Undang No. 2 tentang Sistem Pendidikan Nasional: "Pendidikan Kejuruan merupakan pendidikan yang mempersiapkan peserta didik untuk dapat bekerja dalam bidang tertentu."

4) Peraturan Pemerintah nomor 29 tahun 1990 tentang Pendidikan Menengah, yaitu: pendidikan menengah Kejuruan adalah pendidikan pada jenjang pendidikan menengah yang mengutamakan pengembangan kemampuan sisiwa untuk pelaksanaan jenis pekerjaan tertentu."

Pendidikan menengah kejuruan mengutamakan penyiapan siswa untuk memasuki lapangan kerja serta mengembangkan sikap profesional. Sesuai dengan bentuknya, sekolah menengah kejuruan menyelenggarakan program-program pendidikan yang disesuaikan dengan jenis-jenis lapangan kerja.

Penelitian dan pengembangan merupakan penelitian yang dilakukan berdasarkan analisis kebutuhan lapangan, yang nantinya akan digunakan sebagai landasan penyusunan draft pengembangan dan akan menghasilkan suatu produk pengembangan baru atau penyempurnaan produk yang telah ada. Produk pengembangan ini akan disesuaikan dengan karakteristik siswa sehinga diharapkan dalam penggunaannya akan tepat sasaran. Pengembangan model pembelajaran smash bolavoli ini menekankan untuk siswa sekolah menengah kejuruan dengan model yang lebih mudah, menarik, menyenangkan, dan tidak membosankan sehingga dapat membantu siswa dalam mempelajari materi smash bolavoli dengan mudah.

Tujuan penelitian ini yaitu: (1). Menghasilkan produk berupa model pembelajaran smash bolavoli untuk siswa SMK. (2). Memperoleh data empiris tentang efektivitas model pembelajaran smash bolavoli untuk siswa SMK.

\section{METODOLOGI PENELITIAN}

Pendekatan penelitian pengembangan pembelajaran smash bolavoli ini menggunakan model penelitian dan pengembangan (Research and Development) dari Borg dan Gall. Teknik analisis data yang digunakan dalam penelitian ini adalah teknik analisis kualitatif dan teknik analisis kuantitatif. Teknik analisis kualitatif digunakan untuk menganalisis data yang diperoleh dari para ahli berupa saran dan masukan yang tidak dapt dirubah ke dalam bentuk angka, sedangkan teknik analisis kuantitatif digunakan untuk mengelola data yang didapat dari hasil uji coba kelompok kecil dan uji coba lapangan kelompok besar serta uji efektivitas model. 


\section{HASIL DAN PEMBAHASAN PENELITIAN}

\section{a. Hasil Analisis Kebutuhan}

Hasil dari analisis kebutuhan menunjukkan bahwa:

1. Pendidikan jasmani merupakan salah satu wadah yang sangat penting didalam menunjang tercapainya tujuan siswa SMK didalam berkarir kedepannya. Melalui Pendidikan jasmani sangat penting dalam membangun karakter dan kepribadian siswa/i SMK yang siap terjun di dunia kerja dan industri. Namun saat ini, pendidikan jasmani di SMK sangat memprihatinkan karena adanya pengurangan jam mengajar dan menghilangkan jam pelajaran olahraga untuk kelas XII.

2. Tuntutan di dalam dunia kerja, lulusan SMK tidak hanya dituntut sebuah keterampilan bekerja tetapi juga dibutuhkan seorang lulusan SMK yang memiliki badan yang sehat, bugar, berkarakter dan kepribadian baik yang dibentuk melalui pendidikan jasmani.

3. Materi pembelajaran penjas di SMK secara umum yaitu permainan bola besar, permainan bola kecil, senam, aerobik dan atletik. Materi pendukung yang berkaitan kesehatan yaitu mencakup pendidikan kesehatan pribadi, ilmu gizi, bahaya NAPZA, kesehatan lingkungan dan dampak pergaulan bebas.

4. Materi smash yang terdapat dalam buku pendidikan jasmani di SMK masih sangat kurang. Materi smash dalam buku pendidikan jasmani di SMK kurang variatif dan model pembelajarannya sedikit. Dibuku penjas SMK, materi smash bolavoli masih umum hanya sebatas menjelaskan teknik smash, belum ada langkah-langkah pembelajaran smash secara bertahap.

5. Model pembelajaran smash yang selama ini sudah dilakukan oleh guru SMK masih menggunakan model yang biasa digunakan sehari-hari dalam pembelajaran smash. Kondisi ini mencerminkan bahwa model pembelajaran smash yang dilakukan saat ini masih monoton, kurang variatif, inovatif dan kreatif. Kondisi ini secara tidak langsung menurunkan minat dan antusias siswa dalam mengikuti pembelajaran smash bola voli menjadi rendah.

6. Sebagian siswa beranggapan bahwa gerakan smash merupakan gerakan yang sulit, sehingga siswa cendrung melakukan gerakan smash sama seperti melakukan servis atas.

7. Guru sudah berupaya maksimal dalam memberikan materi smash agar anak lebih tertarik mengikuti pembelajaran smash, dengan membaca referensi buku penjas dan melihat video - video bolavoli khususnya smash dan membuat langkah yang mudah didalam pembelajarannya. Membuat model pembelajaran yag berbeda dengan sebelumnya atau memodifikasi pembelajaran agar lebih mudah dan menyenangkan. 
8. Secara keseluruhan guru menyatakan bahwa pengembangan model pembelajaran smash bolavoli sangat dibutuhkan untuk menunjang proses Kegiatan Belajar Mengajar (KBM) dan pelengkap buku pelajaran penjas di SMK yang masih kurang, terutama materi smash.

\section{b. Kelayakan Model}

Berdasarkan hasil uji kelayakan model pembelajaran smash tanpa media bola, dari 13 model yang peneliti susun menjadi 10 model. Terdapat 3 model yang tidak layak yakni: Model Pembelajaran Smash Ayun Tangan Satu Langkah Lompat, Model Pembelajaran Smash Ayun Tangan Dua Langkah Lompat dan Model Pembelajaran Smash Ayun Tangan Tiga Langkah Lompat.

Ketiga model di atas berdasarkan hasil uji justifikasi ahli, model pembelajaran smash ayun tangan satu langkah lompat dari 4 aspek yang dinilai yakni tujuan, gambar, sarana dan prasarana, pelaksanaan diperoleh nilai rata-rata 0,45 (45\%). Model pembelajaran smash ayun tangan dua langkah lompat diperoleh nilai rata-rata 0,50 (50\%). Model pembelajaran smash ayun tangan tiga langkah lompat diperoleh nilai rata-rata 0,45 (45\%). Perolehan hasil justifikasi ahli ketiga model pada pengembangan ini dapat dikategorikan tidak layak untuk digunakan dalam pengembangan model pembelajaran smash.

Berdasarkan hasil uji kelayakan model pembelajaran smash dengan media bola, dari 21 model yang peneliti susun menjadi 16 model. Terdapat 5 model yang tidak layak yakni: Model Pembelajaran Smash Tabotentaka (Tangkap Bola Tenis Tangan Kanan), Model Pembelajaran Smash Tabotentaki (Tangkap Bola Tenis Tangan Kiri), Model Pembelajaran Smash Lembovoltaka (Lempar Bola Voli Tangan Kanan), Model Pembelajaran Smash Lembovoltaki (Lempar Bola Voli Tangan Kiri), dan Model Pembelajaran Smash Tangkap Bola Voli.

Kelima model di atas berdasarkan hasil uji justifikasi ahli, yang dinilai dari 4 aspek yang dinilai yakni tujuan, gambar, sarana dan prasarana, pelaksanaan, model pembelajaran smash tabotentaka (tangkap bola tenis tangan kanan) diperoleh nilai ratarata 0,45 atau (45\%). Model pembelajaran smash tabotentaki (tangkap bola tenis tangan kiri) diperoleh nilai rata-rata 0,45 atau (45\%). Model pembelajaran smash Lembovoltaka (Lempar Bola Voli Tangan Kanan) diperoleh nilai rata-rata 0,40 atau (40\%). Model pembelajaran smash Lembovoltaki (Lempar Bola Voli Tangan Kiri) diperoleh nilai rata-rata 0,40 atau (40\%). Model pembelajaran smash Tangkap Bola Voli diperoleh nilai rata-rata 0,50 atau (50\%).Perolehan hasil justifikasi ahli kelima model pada pengembangan ini dapat dikategorikan tidak layak untuk digunakan dalam pengembangan model pembelajaran smash. 


\section{c. Efektivitas Model}

\section{1) Hasil Uji Coba Kelompok Kecil}

Uji coba kelompok kecil akan diperoleh data tentang kemudahan dan kemenarikan model pembelajaran smash yang dilaksanakan pada siswa SMK 32 Jakarta. Subjek uji coba dalam uji coba kelompok kecil sebanyak 36 siswa SMK yang diambil secara acak. Data diambil dengan cara memberikan instrumen berupa angket kuisioner.

Setelah data diperoleh kemudian dihitung rata-rata persentase hasil dari jumlah jawaban yang diperoleh dari pengisian angket tersebut.

Tabel 1. Hasil Analisis Data Uji Coba Kelompok Kecil

\begin{tabular}{|c|c|c|c|c|c|}
\hline No & Variabel & $\begin{array}{c}\text { Skor } \\
\text { Hasil }\end{array}$ & Skor Maksimal & \% & Keterangan \\
\hline 1 & Kemudahan & 3571 & 4680 & 76,30 & Baik \\
\hline 2 & Kemenarikan & 3770 & 4680 & 80,56 & Sangat Baik \\
\hline
\end{tabular}

Berdasarkan tabel di atas kemudahan model pembelajaran smash diperoleh nilai 76,30\% dan dinyatakan baik. Berdasarkan kemenarikan model pembelajaran smash diperoleh nilai $80.56 \%$ dan dinyatakan sangat baik. Hasil analisis data uji coba kelompok kecil pada tabel di atas terhadap siswa SMK dapat disimpulkan bahwa model pembelajaran smash untuk siswa SMK dapat dilanjutkan ke uji coba kelompok besar dengan beberapa catatan diantaranya: 1) penggunaan sarana pada model pembelajaran smash sebagian harus direvisi karena dirasa sulit untuk dilakukan oleh siswa SMK, 2) frekuensi gerakan dari masing-masing model pembelajaran ditingkatkan, 3) jarak antar kelompok pada model pembelajaran yang berkelompok disesuaikan dengan kondisi dilapangan.

\section{2) Hasil Uji Coba Kelompok Besar}

Berikut akan disajikan pengolahan data hasil evaluasi uji coba kelompok besar terhadap produk pengembangan model pembelajaran smash dengan sampel 216 siswa SMK dari 3 Sekolah SMK yang diambil (SMK 17 Agustus, SMK Asisi, SMK Krisanti).

Tabel 2. Hasil Analisis Data Uji Coba Kelompok Besar

\begin{tabular}{cccccc}
\hline No & Variabel & $\begin{array}{c}\text { Skor } \\
\text { Hasil }\end{array}$ & Skor Maksimal & \% & Keterangan \\
& & & & \\
\hline 1 & Kemudahan & 20148 & 28080 & 71,75 & Baik \\
\hline 2 & Kemenarikan & 21162 & 28080 & 75,36 & Baik \\
\hline
\end{tabular}


Berdasarkan kemudahan siswa SMK mempraktekkan model pembelajaran yang dikembangkan diperoleh rata-rata persentase $71,75 \%$. Sedangkan berdasarkan kemenarikan siswa SMK dari model pembelajaran yang dikembangkan diperoleh ratarata presentase $75,36 \%$. Dari hasil tersebut menunjukkan bahwa pada uji coba kelompok besar secara keseluruhan, pengembangan model pembelajaran smash dinyatakan baik dan dapat digunakan pada proses pembelajaran dengan beberapa perbaikan diantaranya: 1) alat yang digunakan lebih ditingkatkan kualitasnya dan mudah didapat dengan memanfaatkan sarana disekolah pada umumnya, 2) pada model pembelajaran smash dapat divariasikan lagi dengan penggunaan sarana pembelajaran yang banyak, 3) frekuensi pembelajaran pada smash lebih diperbanyak.

\section{3) Uji Efektivitas Produk Model Pembelajaran Smash}

Setelah revisi produk akhir selesai kemudian produk dieksperimenkan untuk mengetahui efektivitas dari produk pengembangan tersebut. Uji efektivitas produk ini menggunakan rancangan one group pretest-posttest design, yaitu dengan melakukan pretest atau tes awal dan melakukan posttest atau tes akhir untuk kelompok eksperimen. Untuk mengetahui efektivitas produk pengembangan model pembelajaran smash bolavoli pada Sekolah Menengah Kejuruan menggunakan uji perbedaan rerata.

Tabel 3. Uji Perbedaan Efektivitas Model Pembelajaran Smash Bolavoli

\begin{tabular}{|c|c|c|c|c|}
\hline Sampel & Db & t-hitung & t-table $\boldsymbol{\alpha}=\mathbf{0 , 0 5}$ & Keputusan \\
\hline 34 & 33 & 11,895 & 2,042 & Ditolak \\
\hline
\end{tabular}

Keterangan:

$\mathrm{db} \quad$ : derajat bebas

t-hitung : : hargat-hitung

t-tabel : Harga t-tabel pada taraf signifikan $\alpha(0,05)$

Berdasarkan analisis data diperoleh $\mathrm{t}_{0}$ sebesar 11,895 dan $\mathrm{t}_{\text {tabel }}$ 2,042 dengan derajat bebas 33 dan $\alpha=0,05$. Dengan demikian, $t_{0}=11,895>t_{\text {tabel }}=2,042$ atau $\mathrm{H}_{0}$ ditolak. Karena $\mathrm{H}_{0}$ ditolak maka $\mathrm{H}_{1}$ diterima, terdapat perbedaan antara hasil smash setelah diberikan model pembelajaran smash untuk siswa SMK pada tes awal dan tes akhir.

Hasil akhir produk pengembangan model pembelajaran smash untuk siswa SMK setelah dilakukan penelitian yaitu berupa buku model pembelajaran smash. Pengembangan buku pembelajaran smash untuk siswa SMK berdasarkan atas analisis kebutuhan pembelajaran pendidikan jasmani materi bolavoli. Setelah menganalisis kebutuhan model pembelajaran smash sangat penting peneliti membuat 34 model. 
Model pembelajaran terdiri dari dua tahapan yakni model pembelajaran smash tanpa media bola dan dengan menggunakan media bola. Model yang sudah disusun kemudian diserahkan kepada 5 orang ahli untuk diminta validasi tentang model yang peneliti susun.

Berdasarkan hasil uji kelayakan model pembelajaran smash yang dilakukan terhadap 34 model pembelajaran. Berdasarkan hasil uji kelayakan model pembelajaran smash tanpa media bola, dari 13 model yang peneliti susun menjadi 10 model. Terdapat 3 model yang tidak layak yakni: (1). Model pembelajaran smash ayun tangan satu langkah lompat. (2) Model pembelajaran smash ayun tangan dua langkah lompat. (3). model pembelajaran smash ayun tangan tiga langkah lompat.

Ketiga model di atas berdasarkan hasil uji justifikasi ahli, model pembelajaran smash ayun tangan satu langkah lompat dari 4 aspek yang dinilai yakni tujuan, gambar, sarana dan prasarana serta pelaksanaan diperoleh nilai rata-rata dibawah $50 \%$. Sehingga ketiga model pada pengembangan ini dapat dikategorikan tidak layak untuk digunakan dalam pengembangan model pembelajaran smash. Catatan para ahli, ketiga model di atas dinyatakan tidak layak karena model tersebut memiliki kesamaan dengan model yang sudah ada di model pembelajaran smash dengan media bola. Ketiga model pembelajaran ini juga memiliki kemiripan dengan model pembelajaran langkah dan model pembelajaran smash shadaw.

Hasil uji kelayakan model pembelajaran smash dengan media bola, dari 21 model yang peneliti susun menjadi 16 model. Terdapat 5 model yang tidak layak yakni: (1). Model pembelajaran smash tabotentaka (tangkap bola tenis tangan kanan) (2). Model pembelajaran smash tabotentaki (tangkap bola tenis tangan kiri). (3). Model Pembelajaran Smash Lembovoltaka (Lempar Bola Voli Tangan Kanan). (4). Model pembelajaran smash lembovoltaki (lempar bola voli tangan kiri). (5). Model pembelajaran smash tangkap bola voli.

Kelima model di atas berdasarkan hasil uji justifikasi ahli, model pembelajaran smash ayun tangan satu langkah lompat dari 4 aspek yang dinilai yakni tujuan, gambar, sarana dan prasarana serta pelaksanaan diperoleh nilai rata-rata dibawah $50 \%$. Sehingga ketiga model pada pengembangan ini dapat dikategorikan tidak layak untuk digunakan dalam pengembangan model pembelajaran smash. Catatan para ahli, kelima model di atas dinyatakan tidak layak karena gerakan smash yang ada dirasa kurang efektif karena gerakan smash hanya gerakan menangkap. Gerakan smash yang dilakukan tidak hanya diam tapi ada gerakan melangkah dan melompat sambil memukul bola tenis.

Berdasarkan hasil uji coba kelompok kecil dan uji coba kelompok besar diperoleh data sebagai berikut. Dari hasil uji coba kelompok kecil diperoleh hasil 
kriteria ditinjau aspek kemudahan model pembelajaran smash bola voli diperoleh nilai $76,30 \%$ dan dinyatakan sangat baik. Sedangkan ditinjau dari aspek kemenarikan model pembelajaran smash bola voli diperoleh nilai $80.56 \%$ dan dinyatakan sangat baik.

Hasil uji coba kelompok kecil memiliki nilai positif, maka peneliti melanjutkan untuk uji coba skala besar dengan melibakan 216 subjek dari 3 SMK yang berada di wilayah Jakarta Selatan. Dari hasil uji coba kelompok besar diperoleh hasil kriteria ditinjau aspek kemudahan model pembelajaran smash bola voli diperoleh nilai 71,75\% dan dinyatakan baik. Sedangkan ditinjau dari aspek kemenarikan model pembelajaran smash bola voli diperoleh nilai 75,36\% dan dinyatakan baik.

Berdasarkan perumusan masalah peneliti ingin melihat kefektifan dari 26 model yang dikembangkan dan diterapkan kepada siswa SMK, hasil yang diperoleh menunjukan $t_{0}$ sebesar 11,895 dan $t_{\text {tabel }} 2,042$ dengan derajat bebas 33 dan $\alpha=0,05$. Dengan demikian, $\mathrm{t}_{0}=11,895>\mathrm{t}_{\text {tabel }}=2,042$ atau $\mathrm{H}_{0}$ ditolak. Karena $\mathrm{H}_{0}$ ditolak maka $\mathrm{H}_{1}$ diterima, sehingga dapat disimpulkan terdapat perbedaan antara hasil smash bola voli siswa SMK setelah diberikan 26 model pembelajaran smash yang peneliti susun.

Model pembelajaran smash pada siswa SMK yang dikembangkan peneliti memiliki kelebihan yaitu:

1. Model pembelajaran ini disusun dengan desain gerakan yang sederhana hingga kompleks.

2. Menyajikan model pembelajaran yang aktif, efektif dan efisien dan dapat dilakukan oleh semua siswa SMK yang sudah mendapatkan materi teknik dasar bola voli.

3. Siswa SMK lebih aktif dalam proses pembelajaran.

4. Alat yang digunakan sederhana dan biasa digunakan dalam kegiatan pembelajaran pendidikan jasmani di sekolah.

Sedangkan kelemahan dari model pembelajaran smash bola voli yang dikembangkan peneliti memiliki kelemahan yaitu:

1. Model pembelajaran ini untuk tingkat mahir maka siswa SMK yang tidak menguasai materi teknik dasar bola voli membutuhkan waktu yang sedikit lebih lama untuk mempraktekkan semua gerakan.

2. Model pembelajaran ini terdiri dari gerakan-gerakan yang sederhana ke gerakan yang sesungguhnya, sehingg masih diperlukan pengembangan guru ketika diterapkan dalam pembelajaran, agar siswa tidak cepat bosan.

\section{KESIMPULAN}


1. Hasil analiis kebutuan menunjukan bahwa model pembelajaran smash bola voli sangat dibutuhkan oleh para guru pendidikan jasmani untuk menunjang proses Kegiatan Belajar Mengajar (KBM) dan pelengkap buku pelajaran penjas di SMK yang masih kurang, terutama materi smash. Berdasarkan 34 pengembangan model pembelajaran smash bola voli yang disusun peneliti, hasil validasi dari 5 ahli berdasarkan 4 aspek yang dinilai yakni tujuan, gambar, sarana dan prasarana serta pelaksanaan terdapat 8 model yang masih memperoleh nilai rata-rata dibawah $50 \%$. Sehingga pada penggunaan keseluruhan model pada pengembangan ini yang dikategorikan layak serta cocok untuk digunakan sebanyak 26 model pembelajaran smash bola voli. Hasil uji coba kelompok kecil diperoleh hasil kriteria ditinjau aspek kemudahan model pembelajaran smash bola voli diperoleh nilai 76,30\% dan dinyatakan baik, sedangkan aspek kemenarikan diperoleh nilai $80.56 \%$ dan dinyatakan sangat baik. Hasil uji coba kelompok besar diperoleh hasil kriteria ditinjau aspek kemudahan model pembelajaran smash bola voli diperoleh nilai $71,75 \%$ dan dinyatakan baik sedangkan ditinjau dari aspek kemenarikan diperoleh nilai $75.36 \%$ dan dinyatakan baik.

2. Keefektifan model yang dikembangkan dinyatakan efektif untuk digunakan. Berdasarkan dari hasil perbandingan antara nilai pretest dan posttest yang diberikan kepada siswa diperoleh hasil to sebesar 11,895 dan $t_{\text {tabel }} 2,042$. Dengan demikian, $\mathrm{t}_{0}=11,895>\mathrm{t}_{\text {tabel }}=2,042$ atau $\mathrm{H}_{0}$ ditolak. Sehingga dapat disimpulkan terdapat perbedaan antara hasil smash bola voli peserta didik setelah diberikan model pembelajaran smash bola voli.

\section{DAFTAR PUSTAKA}

Ace Suryadi, Pendidikan Investasi SDM, Jakarta: Balai Pustaka 2002.

Anas Junaedi dan Heri Wisnu, Survei Tingkat Kemajuan Pendidikan Jasmani, Olahraga, Dan Kesehatan Di SMA, SMK, Dan MA Negeri Se-Kabupaten Gresik. Jurnal Pendidikan Olahraga dan Kesehatan Volume 03 Nomor 03 Tahun 2015, $834-842$

Borg. W. R \& Gall, M. D, Educational Research An Introduction New York: Longman, 2002.

Direktorat Keolahragaan, Pemuda dan Olahraga, Olahraga Bolavoli, Jakarta: Depdikbud, 1986.

Husdarta dan Nurlan Kusmaedi, Pertumbuhan dan Perkembangan (Olahraga dan Kesehatan), Bandung: Alfabeta, 2010. 
Kinda Lenberg American Volleyball Coachhes Association-Vollleyball Skill and Drills. United States of America: Human Kinetics: 2006

Novi Dian Anggraini dkk. Pengembangan Pembelajaran Teknik Dasar Service bawah Bolavoli Untuk Siswa Kelas VIII SMP Negeri 5 Malang. Jurnal Olahraga Pendidikan, Volume 1 No 1 Tahun 2014 h. 82

Samsudin. Kurikulum Pendidikan Jasmani Olahraga dan Kesehatan Jakarta: FIK UNJ 2008.

Soedjatmiko, Atip Nurcahyani, Membentuk Karakter Siswa Sekolah Dasar Menggunakan Pendidikan Jasmani Dan Olahraga, Journal of Physical Education, Health and Sport 2 (2) (2015)

Sugiyono, Metode Penelitian Pendidikan: Pendekatan Kuantitatif, Kualitatif, dan $R \& D$. Bandung: Alfabeta. 2012.

Tangkudung James, Macam-macam Metodologi Penelitian Uraian dan Contohnya Jakarta: Lensa Media Pustaka, 2016.

Tegar Bayu Kharisma, Pengembangan Pembelajaran Permainan Bolavoli Mini, Jurnal Olahraga Pendidikan, Volume 1 No 1 Tahun 2014 h. 9

Wardiman Djojonegoro, Pengembangan Sumber Daya Manusia Melalui Sekolah Menengah Kejuruan (SMK), Jakarta: Jayakarta Agung Ofset, 1998. 